\title{
DIVERSITY OF WEED FLORA, SELECTED BIOMETRIC CHARACTERISTICS AND YIELDING OF Miscanthus spp. CULTIVATED ON LIGHT AND HEAVY SOIL
}

\author{
Beata Feledyn-Szewczyk, Mariusz Matyka, Mariola Staniak \\ Institute of Soil Science and Plant Cultivation-State Research Institute \\ Czartoryskich 8, 24-100 Puławy, Poland \\ e-mail: bszewczyk@iung.pulawy.pl
}

Received: 29.03 .2013

\begin{abstract}
An important issue related to the cultivation of plants for energy purposes and poorly recognized so far is their impact on the environment, including biodiversity. The aim of the work was to assess weed flora diversity, canopy structure and yield of miscanthus cultivated on two types of soil: light and heavy.

The study was carried out in the Experimental Station of the Institute of Soil Science and Plant Cultivation - State Re-

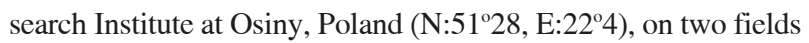
of miscanthus (Miscanthus saccharflorus Robustus $x$ M. sinensis - M-115) established in 2004, on light loamy sand and heavy loam. The analysis of weed flora was carried out in 2010 and 2011, in mid-June and mid-August, using two methods: the frame method and phytosociological relevés. Moreover, an analysis of green and dry matter yield of miscanthus, some biometric features and leaf area index (LAI) was carried out.

The results showed that weed species diversity in a miscanthus crop was dependent on soil type. A larger number of weed species was found in miscanthus cultivated on heavy soil 37 - in comparison with miscanthus cultivated on light soil - 33 . Sorensen's indicators showed low similarity between weed communities in miscanthus on light and heavy soil. Weed abundance and percentage of weed cover were lower in miscanthus cultivated on light soil. Weed density decreased during the vegetation season as a result of increasing competitiveness of the miscanthus canopy against weeds. Miscanthus yields were more dependent on weather conditions than the type of soil. Plant height and shoot diameter as well as leaf area index (LAI) were higher in miscanthus grown on heavy soil.
\end{abstract}

Key words: Miscanthus, biometric features, plants for energy purposes, weeds, biodiversity

\section{INTRODUCTION}

The impact of perennial crops cultivated for energy purposes on biodiversity is still poorly under- stood, because it is a new direction in agricultural production. Cultivation of these plants on a global scale contributes to reduce $\mathrm{CO}_{2}$ emissions and decrease erosion and nutrient leaching as well as it is used for phytoremediation of contaminated soils [1-3]. The environmental effect of these plantations may depend on the species and genotype of cultivated plants, previous land use, agricultural practices, the size and spatial distribution of crops as well as the degree of integration into the regional landscape [4,5]. Most concerns related to planting energy crops, in addition to the depletion of water resources, arise from their potential impact on biodiversity [2]. Some authors suggest that the cultivation of perennial plants, compared with the impact of intensive technology using annual plants, has a positive effect on biodiversity due to a lower input of agrochemicals [4-6]. S a g e at al. [7] pointed out that the physical structure of the canopy, rapid growth rate, high density, chemical crop protection and mineral fertilization caused habitats of plants cultivated for energy purposes not to be conducive to flora and fauna diversity. However, the biodiversity potential is dependent on the approach taken to control pests and on the use of pesticides [8]. In addition, large monocultures of perennial energy crops could provide visual barriers to open agricultural landscape $[9,10]$.

The studies on plant communities in crops cultivated for energy purposes indicate a high diversity of the flora accompanying short rotation coppice crops (SRC), especially willow (Salix viminalis) and poplar (Populus spp.), in comparison with arable lands, and a positive impact on diversity of birds [6,10-17]. There are very few papers related to the effect of cultivation of miscanthus and other energy crops on biodiversity, especially flora $[10,18]$. Preliminary studies showed 
that miscanthus may be a poorer habitat for flora and fauna than the SRC [19]. According to J od 1 et al. [20], tall miscanthus stands contain more large animals (mammals, birds) than other herbaceous crops (maize or reeds), possibly due to the greater diversity of the canopy structure leading to a higher number and greater range of ecological niches.

The aim of the work was to assess weed flora diversity, canopy structure and yield of miscanthus cultivated on two types of soil.

\section{MATERIALS AND METHODS}

The study was carried out in the years 2010 2011 in the fields of miscanthus (Miscanthus saccharflorus Robustus $x$ M. sinensis - M-115) located in the Experimental Station of IUNG-PIB at Osiny, Lublin region $\left(\mathrm{N}: 51^{\circ} 28, \mathrm{E}: 22^{\circ} 4\right)$. The plantations of $200 \mathrm{~m}^{2}$ were established in 2004 on two types of soil: light loamy sand and heavy loam.

The fields had been previously used as arable land, maintained in good agricultural condition. Miscanthus seedlings, produced in vitro in Germany, were used. They were planted out in mid-May 2004 in an amount of $15,000 \times \mathrm{ha}^{-1}$. Every year mineral fertilizers were applied as follows: $\mathrm{N}-75, \mathrm{P}_{2} \mathrm{O}_{5}-50$, and $\mathrm{K}_{2} \mathrm{O}-75 \mathrm{~kg}$ $\times \mathrm{ha}^{-1}$. Weed control treatments were not used during the study period, only mechanical weeding was done in the first year after the establishment of the experiment. Harvest of plants and sampling for biometric analysis were carried out after the growing season, in winter.

Weather conditions during the study period, compared to the long-term average, are presented on Fig. 1 .

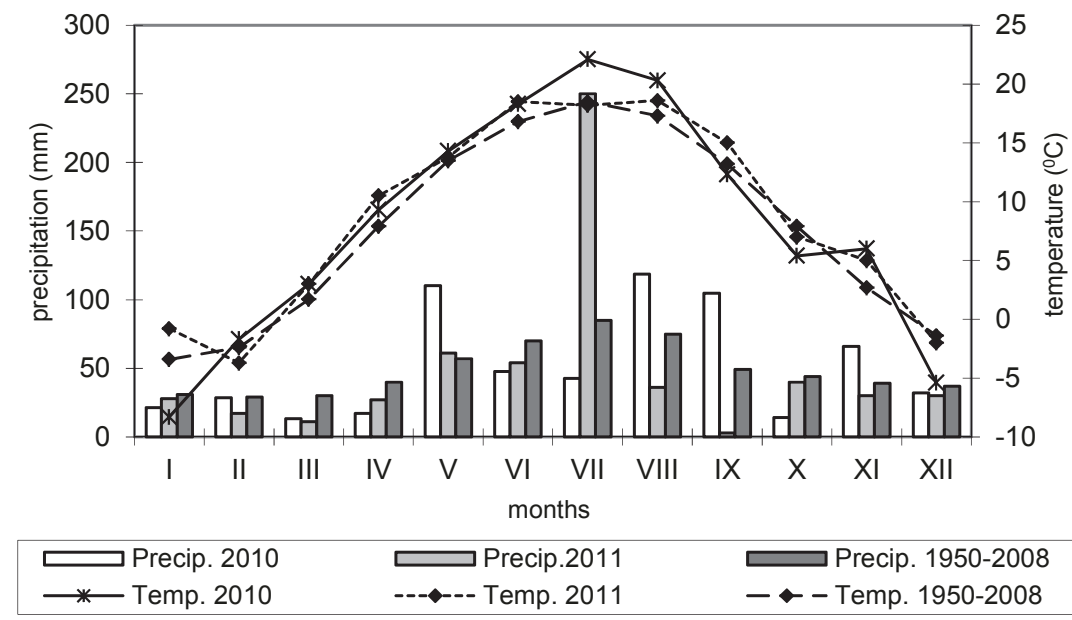

Fig. 1. Average monthly air temperature $\left({ }^{\circ} \mathrm{C}\right)$ and total precipitation $(\mathrm{mm})$ in 2010-2011 compared to the long-term average (1950-2008)

In 2010 bad weather conditions and frost in the spring until mid-May caused a delay in the start of plant growth, especially in miscanthus grown on heavy soil (Fig. 1). The growing season was characterized by an unequal, irregular distribution of temperature and precipitation: heavy rainfall in May and August, a high temperature and drought in June and July, which could have affected weed infestation. In the winter of 2011, minimal snow cover and periodic thaw occurred, which could have affected the growth of miscanthus. Intensive rainfall in July exceeded twice the long-term mean, but in August and September very low precipitation was observed (Fig. 1).

The analysis of weed flora was carried out using two methods: the frame method (all plants in an area of $0.5 \mathrm{~m}^{2}$ were counted) and phytosociological relevés (the percentage cover of weeds in an area of $25 \mathrm{~m}^{2}$ was assessed), in four replications. The surveys were done in mid-June and mid-August. The structure of weed communities was analysed using ecological indices: Shannon's diversity index, Simpson's dominance index and Sorensen's indices of similarity [21-23]. The similarity is low if the percentage is up to $39.0 \%$, moderate -40.0 to $49.0 \%$, high -50.0 to $59.0 \%$, and very high if it is more than $60.0 \%$ [23]. Plant species were identified according to $\mathrm{R} \mathrm{u} \mathrm{t} \mathrm{k} \mathrm{o} \mathrm{w} \mathrm{s} \mathrm{k} \mathrm{i} \mathrm{[24].}$

The analysis of green and dry matter yield of miscanthus, some morphological features: the number of shoots per plant, their length and diameter at $10 \mathrm{~cm}$ above the ground, was carried out on 10 plants in 5 replications. Moreover, the leaf area index (LAI) was assessed at the beginning of July using a LI-2000 canopy analyzer (LI-COR). The dry weight was determined by placing the green matter in a dryer at $80^{\circ} \mathrm{C}$ for 14 days.

To determine the significance of differences, an analysis of variance was done using Tukey's test at a significance level of $p=0.05$. As a number of weeds 
did not have a normal distribution, a logarithmic transformation of data was performed prior to the analysis of variance. Calculations were performed using Statgraphic Plus version 2.1.

\section{RESULTS}

The results showed that weed species diversity in miscanthus was dependent on soil type. The average number of weed species was significantly higher in miscanthus cultivated on heavy soil on all analysis dates (Tables 1 and 2). A higher number of species was recorded when the phytosociological method was used in comparison with the frame method. It is due to the larger area of analysis in the phytosociological method than in the frame method with the same number of replications (four) (Tables 1-3). The number of weed species and number of weeds decreased during the growing period due to the increasing competitive ability of the miscanthus canopy (Tables 1-3).

Table 1

Number of weed species in miscanthus cultivated on light and heavy soils recorded using the frame method

\begin{tabular}{ccccccccccc}
\hline \multirow{2}{*}{ Year } & Type of soil & \multicolumn{4}{c}{ June } & \multicolumn{3}{c}{ August } \\
\cline { 3 - 11 } & & mean & range & \pm SD* & CV* & mean & range & \pm SD & CV \\
\hline \multirow{2}{*}{2010} & light & $6.3 \mathrm{a}$ & $5-8$ & 1.3 & 20.2 & $4.0 \mathrm{a}$ & $2-6$ & 1.6 & 40.8 \\
& heavy & $7.8 \mathrm{a}$ & $6-10$ & 1.7 & 22.1 & $8.0 \mathrm{~b}$ & $6-9$ & 1.4 & 17.6 \\
\hline \multirow{2}{*}{2011} & light & $7.3 \mathrm{a}$ & $4-9$ & 2.4 & 32.5 & $4.8 \mathrm{a}$ & $4-6$ & 0.9 & 20.0 \\
& heavy & $10.8 \mathrm{~b}$ & $9-13$ & 2.1 & 19.1 & $7.0 \mathrm{a}$ & $6-8$ & 0.8 & 11.6 \\
\hline \multirow{2}{*}{ average } & light & $6.8 \mathrm{a}$ & $4-9$ & 1.8 & 27.1 & $4.4 \mathrm{a}$ & $2-6$ & 1.3 & 29.7 \\
& heavy & $9.3 \mathrm{~b}$ & $6-13$ & 2.4 & 25.6 & $7.5 \mathrm{~b}$ & $6-9$ & 1.2 & 15.9 \\
\hline
\end{tabular}

* Means were compared between types of soil for each date of analysis. Values followed by the same letters are not significantly different according to Tukey's test ( $\mathrm{p}=0.05)$; $\mathrm{SD}$ - standard deviation; $\mathrm{CV}$ - coefficient of variation

Table 2

Number of weed species in miscanthus cultivated on light and heavy soils recorded using the phytosociological method

\begin{tabular}{cccccccccccc}
\hline \multirow{2}{*}{ Year } & \multirow{2}{*}{ Type of soil } & \multicolumn{4}{c}{ June } & \multicolumn{4}{c}{ August } \\
\cline { 3 - 12 } & & mean & range & \pm SD* & CV* & mean & range & \pm SD & CV \\
\hline \multirow{2}{*}{2010} & light & $10.3 \mathrm{a}^{*}$ & $9-14$ & 2.5 & 24.4 & $4.8 \mathrm{a}$ & $3-7$ & 1.7 & 35.8 \\
& heavy & $13.0 \mathrm{a}$ & $11-16$ & 2.2 & 16.6 & $10.8 \mathrm{~b}$ & $7-14$ & 2.9 & 26.7 \\
\hline \multirow{2}{*}{2011} & light & $10.3 \mathrm{a}$ & $9-12$ & 1.3 & 12.2 & $5.8 \mathrm{a}$ & $5-7$ & 0.9 & 16.5 \\
& heavy & $13.3 \mathrm{~b}$ & $12-15$ & 1.3 & 9.4 & $9.3 \mathrm{~b}$ & $8-12$ & 1.9 & 20.4 \\
\hline \multirow{2}{*}{ average } & light & $10.3 \mathrm{a}$ & $9-14$ & 1.8 & 17.9 & $5.3 \mathrm{a}$ & $3-7$ & 1.4 & 26.3 \\
& heavy & $13.1 \mathrm{~b}$ & $11-16$ & 1.6 & 12.5 & $10.0 \mathrm{~b}$ & $7-14$ & 2.4 & 23.9 \\
\hline
\end{tabular}

* Explanations under Table 1.

The total number of weed species was also higher in miscanthus cultivated on heavy soil where 27 species were found using the frame method and 37 species using the phytosociological method (Table 3).
In miscanthus cultivated on light soil, only 22 weed species were observed when the analysis was performed with the frame method, and 33 species when the phytosociological method was used. 
Table 3

Weed species composition and number of weeds (plants $\times \mathrm{m}^{-2}$ ) in miscanthus cultivated on light and heavy soil (mean for 2010-2011)

\begin{tabular}{|c|c|c|c|c|}
\hline \multirow{3}{*}{ Weed species } & \multicolumn{4}{|c|}{ Type of soil and date of analysis } \\
\hline & \multicolumn{2}{|c|}{ light } & \multicolumn{2}{|c|}{ heavy } \\
\hline & June & August & June & August \\
\hline 1. Viola arvensis Murray & 24.0 & 0.0 & 0.0 & 0.0 \\
\hline 2. Conyza canadensis (L.) Cronquist & 10.5 & 5.8 & 1.4 & 7.8 \\
\hline 3. Capsella bursa-pastoris (L.) Med. & 9.8 & 0.0 & 21.9 & 0.8 \\
\hline 4. Lectuca serriola $\mathrm{L}$. & 5.4 & 1.3 & 3.8 & 1.8 \\
\hline 5. Taraxacum officinale Weber & 5.3 & 1.8 & 1.5 & 4.5 \\
\hline 6. Crepis tectorum $\mathrm{L}$. & 1.3 & 0.0 & 0.3 & 0.0 \\
\hline 7. Arabidopsis thaliana (L.) Heynh. & 1.1 & 0.0 & 0.0 & 0.0 \\
\hline 8. Geranium dissectum $\mathrm{L}$. & 0.8 & 0.3 & 0.0 & 0.0 \\
\hline 9. Spergula arvensis L. & 0.6 & 0.0 & 0.0 & 0.0 \\
\hline 10. Chenopodium album $\mathrm{L}$. & 0.4 & 0.8 & 10.9 & 2.3 \\
\hline 11. Solidago gigantea Aiton & 0.3 & 1.5 & 0.5 & 0.8 \\
\hline 12. Achillea millefolium $\mathrm{L}$. & 0.3 & 0.3 & 0.0 & 0.0 \\
\hline 13. Cerastium arvense $\mathrm{L}$. & 0.3 & 0.3 & 0.0 & 0.0 \\
\hline 14. Plantago major L. & 0.0 & 0.0 & 6.3 & 3.8 \\
\hline 15. Stellaria media (L.) Vill. & 0.0 & 0.3 & 0.5 & 0.0 \\
\hline 16. Lamium purpureum $\mathrm{L}$. & 0.0 & 0.0 & 0.4 & 0.0 \\
\hline 17. Chenopodium polyspermum $\mathrm{L}$. & 0.0 & 0.0 & 3.6 & 3.3 \\
\hline 18. Trifolium arvense $\mathrm{L}$. & 0.0 & 0.0 & 0.3 & 0.0 \\
\hline 19. Tripleurospermum inodorum (L.) Schulz-Bip. & 0.0 & 0.0 & 5.9 & 1.0 \\
\hline 20. Papaver rhoeas $\mathrm{L}$. & 0.0 & 1.5 & 0.0 & 0.0 \\
\hline 21. Cirsium arvense (L.) Scop. & 0.0 & 0.0 & 0.4 & 1.0 \\
\hline 22. Urtica dioica $\mathrm{L}$. & 0.0 & 0.0 & 0.3 & 0.5 \\
\hline 23. Galeopsis tetrahit $\mathrm{L}$. & 0.0 & 0.0 & 3.1 & 0.8 \\
\hline 24. Veronica persica Poir & 0.0 & 0.0 & 0.2 & 0.0 \\
\hline 25. Erigeron annuus (L.) Pers & 0.0 & 0.0 & 0.4 & 0.0 \\
\hline 26. Galium aparine $\mathrm{L}$. & 0.0 & 0.0 & 0.5 & 0.0 \\
\hline 27. Solanum nigrum $\mathrm{L}$. & 0.0 & 0.0 & 0.0 & 1.3 \\
\hline 28. Matricaria discoidea DC. & 0.0 & 0.0 & 0.3 & 0.0 \\
\hline 29. Amaranthus retroflexus L. & 0.0 & 0.0 & 0.0 & 0.5 \\
\hline 30. Rumex acetosa $\mathrm{L}$. & 0.0 & 0.8 & 0.0 & 0.0 \\
\hline 31. Vicia villosa Roth. & 0.0 & 0.0 & 3.3 & 0.0 \\
\hline 32. Galinsoga parviflora Cav. & 0.0 & 0.0 & 7.3 & 0.3 \\
\hline Dicotyledonous total & 59.8 & 14.2 & 72.4 & 30,0 \\
\hline 33. Juncus bufonius L. & 18.0 & 0.0 & 0.0 & 0.0 \\
\hline 34. Echinochloa crus-galli (L.) P.B. & 3.8 & 0.0 & 1.0 & 0.0 \\
\hline 35. Poа апnиа $\mathrm{L}$. & 3.0 & 0.5 & 29.8 & 15.0 \\
\hline 36. Elymus repens (L.) P.B. & 2.8 & 4.0 & 0.0 & 0.5 \\
\hline \multirow{3}{*}{$\begin{array}{l}\text { 37. Festuca ovina } \mathrm{L} \text {. } \\
\text { Monocotyledonous total } \\
\text { 38. Equisetum arvense L. }\end{array}$} & 0.8 & 0.0 & 0.0 & 0.0 \\
\hline & 28.3 & 4.5 & 30.8 & 15,5 \\
\hline & 1.1 & 2.3 & 0.0 & 0.0 \\
\hline Horsetail total & 1.1 & 2.3 & 0.0 & $\mathbf{0 , 0}$ \\
\hline Total number of weeds & 89.1 & 21.0 & 103.2 & 45.5 \\
\hline \multirow{2}{*}{ Total number of species recorded using the frame method } & 19 & 14 & 24 & 17 \\
\hline & \multicolumn{2}{|c|}{22} & \multicolumn{2}{|c|}{27} \\
\hline \multirow{2}{*}{$\begin{array}{l}\text { Total number of species recorded using the frame method } \\
\text { and phytosociological relevés }\end{array}$} & 29 & 16 & 32 & 20 \\
\hline & \multicolumn{2}{|c|}{33} & \multicolumn{2}{|c|}{37} \\
\hline
\end{tabular}


The average number of weeds was higher in miscanthus cultivated on heavy soil than on light soil (respectively, 103 and 89 plants $\times \mathrm{m}^{-2}$ in June and 47 and 20 plants $\times \mathrm{m}^{-2}$ in August on average) (Fig. 2). Percentage weed cover was significantly higher in miscanthus cultivated on heavy soil (70\% in June and 37\% in August) in comparison with miscanthus grown on light soil (23\% in June and $8 \%$ in August). On light soil, there was a bigger difference between the number of weeds and their ground cover, especially in June. It suggests that the weed community consisted of small weeds in contrast to heavy soil where plants were bigger. Number of weeds and weed cover decreased during the vegetation period, which was more evident on light soil. It could have been associated with the characteristics of light soil (the lack of water and nutrients). The differences between years were associated with weather conditions, mainly rainfall and soil water capacity.

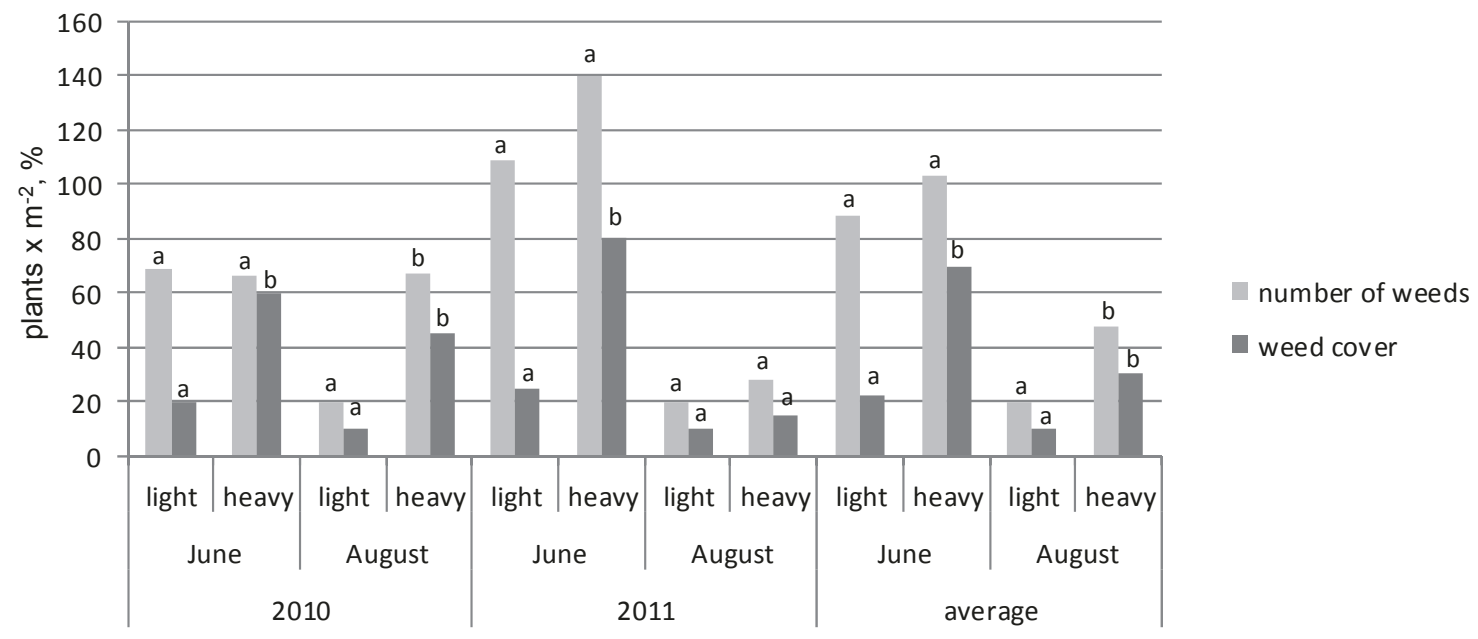

Fig. 2. Number of weeds (plants $\times \mathrm{m}^{-2}$ ) and weed cover $(\%)$ in miscanthus cultivated on light and heavy soil.

* Explanation: Means were compared between types of soil for each date of analysis. Values followed by the same letters are not significantly different according to Tukey's test $(\mathrm{p}=0.05)$

Shannon's diversity index showed a higher diversity of the weed flora community in miscanthus cultivated on heavy soil (fig. 3). Simpson's dominance index was the highest for the weed flora in miscanthus on light soil in August 2010, which was associated with the dominance of Conyza canadensis L. (Cronquist) in the weed community.

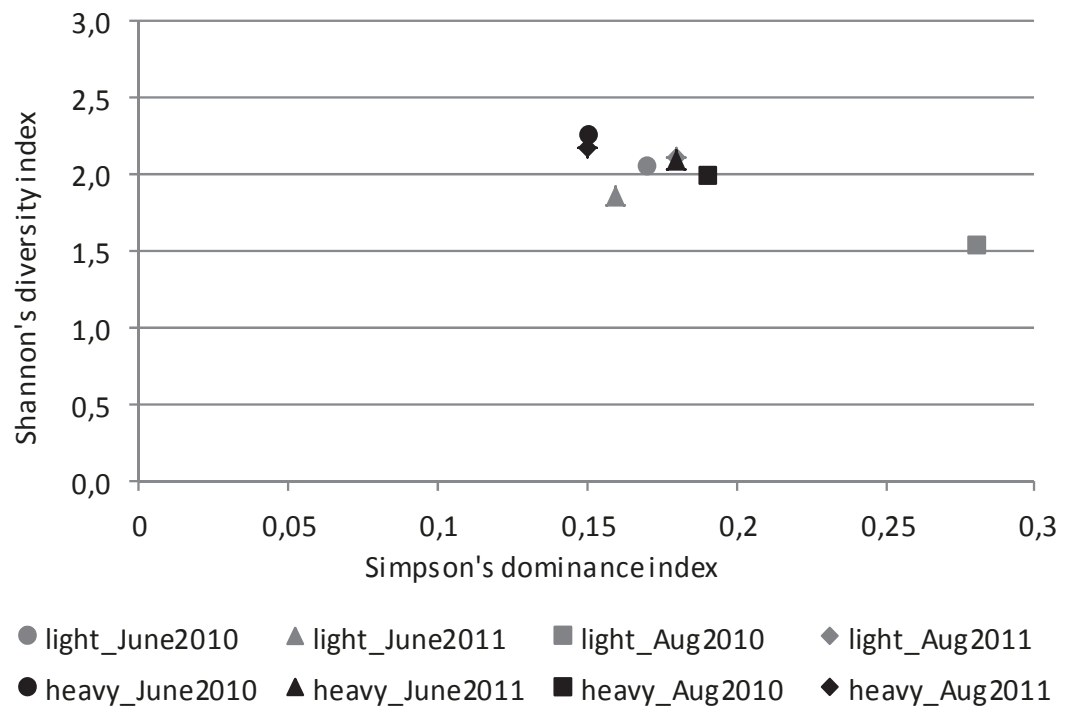

Fig. 3. Shannon's diversity index and Simpson's dominance index for weed communities in miscanthus cultivated on light and heavy soil 
In miscanthus cultivated on heavy soil, species typical for habitats rich in nutrients, especially nitrogen, dominated (Galinsoga parviflora Cav., Chenopodium album L., Galeopsis tetrahit L.), while on light soil species characteristic for poorer habitats occurred (Conyza canadensis (L.) Cronquist, Viola arvensis Murray, Equisetum arvense L.) (Table 3). Only 11 species $(29 \%)$ were common for weed communities in miscanthus on both light and heavy soil. The following species occurred only on light soil: Geranium dissectum L., Viola arvensis Murray, Achillea millefolium L., Papaver rhoeas L., Cerastium arvense L., Arabidopsis thaliana (L.) Heynh., Spergula arvensis L., Rumex acetosa L., Festuca ovina L., Juncus bufonius L, Equisetum arvense L. 16 species were typical only of heavy soil: Plantago major L., Lamium purpureum L., Chenopodium polyspermum L., Trifolium arvense L., Tripleurospermum inodorum (L.) SchulzBip., Cirsium arvense (L.) Scop., Urtica dioica L., Galeopsis tetrahit L., Veronica persica Poir, Erigeron annuus (L.) Pers, Gallium aparine L., Solanum nigrum L., Matricaria discoidea DC., Amaranthus retroflexus L., Vicia villosa Roth., Galinsoga parviflora Cav.).

The qualitative and quantitative indices of similarity confirmed the low similarity of weed communities in miscanthus cultivated in two different types of soil (Table 4). Generally, the values of the qualitative index were higher in comparison to the quantitative ones. It suggests a greater similarity between the weed communities in the species composition than in their numbers. Higher similarity in weed species and their abundance between dates of analysis was observed in miscanthus on heavy soil.

Table 4

Qualitative and quantitative indices of similarity (\%) in miscanthus cultivated in different types of soil

\begin{tabular}{|c|c|c|c|c|c|c|c|c|c|}
\hline & & \multicolumn{8}{|c|}{ Qualitative index of similarity } \\
\hline & & \multicolumn{4}{|c|}{ Light soil } & \multicolumn{4}{|c|}{ Heavy soil } \\
\hline & & $\begin{array}{l}2010 \\
\text { June }\end{array}$ & $\begin{array}{c}2010 \\
\text { August }\end{array}$ & $\begin{array}{l}2011 \\
\text { June }\end{array}$ & $\begin{array}{l}2011 \mathrm{Au}- \\
\text { gust }\end{array}$ & $\begin{array}{l}2010 \\
\text { June }\end{array}$ & $\begin{array}{c}2010 \\
\text { August }\end{array}$ & $\begin{array}{l}2011 \\
\text { June }\end{array}$ & $\begin{array}{c}2011 \\
\text { August }\end{array}$ \\
\hline \multirow{4}{*}{ Light soil } & 2010 June & $\mathrm{X}$ & 50 & 52 & 54 & 39 & 31 & 32 & 38 \\
\hline & 2010 August & 35 & $\mathrm{X}$ & 29 & 60 & 50 & 40 & 32 & 30 \\
\hline & 2011 June & 58 & 22 & $\mathrm{X}$ & 59 & 31 & 30 & 44 & 44 \\
\hline & 2011 August & 15 & 31 & 18 & $X$ & 39 & 38 & 39 & 46 \\
\hline \multirow{4}{*}{ Heavy soil } & 2010 June & 15 & 10 & 21 & 13 & $X$ & 58 & 67 & 65 \\
\hline & 2010 August & 26 & 32 & 26 & 14 & 47 & $\mathrm{X}$ & 65 & 69 \\
\hline & 2011 June & 12 & 7 & 26 & 8 & 48 & 42 & $\mathrm{X}$ & 77 \\
\hline & 2011 August & 17 & 18 & 20 & 29 & 36 & 42 & 24 & $X$ \\
\hline
\end{tabular}

Quantitative index of similarity

$0-39 \%$

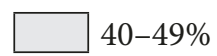

$40-49 \%$
$50-59 \%$
$60-100 \%$
The analysis showed that in 2010 the green and dry matter yield of miscanthus were not dependent on soil quality (Table 5). In 2011 they were significantly higher for miscanthus cultivated on light soil, which could have been associated with good moisture conditions due to high rainfall in June (Fig. 1). The yields of miscanthus on light soil differed significantly between years due to weather conditions.

Table 5

Green and dry matter yield $\left(\mathrm{t} \times \mathrm{ha}^{-1}\right)$ of miscanthus cultivated on light and heavy soil

\begin{tabular}{|c|c|c|c|c|}
\hline \multirow{2}{*}{ Type of soil } & \multicolumn{2}{|c|}{ Green matter yield $\left(\mathrm{t} \times \mathrm{ha}^{-1}\right)$} & \multicolumn{2}{|c|}{ Dry matter yield $\left(\mathrm{t} \times \mathrm{ha}^{-1}\right)$} \\
\hline & 2010 & 2011 & 2010 & 2011 \\
\hline Light soil & $26.9 \mathrm{a}$ & $41.7 \mathrm{~b}$ & $19.8 \mathrm{a}$ & $30.0 \mathrm{~b}$ \\
\hline Heavy soil & $28.3 \mathrm{a}$ & $27.2 \mathrm{a}$ & $19.8 \mathrm{a}$ & $23.0 \mathrm{a}$ \\
\hline
\end{tabular}

*Explanation: Means followed by the same letters are not significantly different according to Tukey’s test ( $\mathrm{p}=0.05)$ 
The biometric parameters, such as shoot length and diameter as well as leaf area index, were higher in miscanthus grown on heavy soil (Table 6). Number of shoots per plant and leaf area index differed significantly between years.

Table 6

Selected biometric characteristics of miscanthus cultivated on light and heavy soil

\begin{tabular}{ccccccccc}
\hline \multirow{2}{*}{ Type of soil } & \multicolumn{2}{c}{ Number of shoots per plant } & \multicolumn{2}{c}{ Plant height $(\mathrm{m})$} & \multicolumn{2}{c}{ Shoot diameter (mm) } & \multicolumn{3}{c}{ Leaf area index (LAI) } \\
\cline { 2 - 9 } & 2010 & 2011 & 2010 & 2011 & 2010 & 2011 & 2010 & 2011 \\
\hline Light soil & $76.0 \mathrm{a}$ & $157.0 \mathrm{~b}$ & $2.21 \mathrm{a}$ & $2.13 \mathrm{a}$ & $4.09 \mathrm{a}$ & $4.55 \mathrm{a}$ & $3.70 \mathrm{a}$ & $5.35 \mathrm{~b}$ \\
Heavy soil & $103.0 \mathrm{a}$ & $78.0 \mathrm{a}$ & $2.56 \mathrm{a}$ & $3.76 \mathrm{a}$ & $6.68 \mathrm{ab}$ & $8.44 \mathrm{~b}$ & $5.30 \mathrm{~b}$ & $7.25 \mathrm{c}$ \\
\hline
\end{tabular}

Explanation: * Means followed by the same letters are not significantly different according to Tukey's test ( $\mathrm{p}=0.05)$

Despite more suitable biometric parameters, such as plant height, shoot diameter and LAI of miscanthus cultivated on heavy soil, the average number of weeds and weed cover were higher than on light soil. This was caused by better soil conditions, especially water and nutrient availability, which favored the growth and development of weeds. Moreover, the vegetation of miscanthus on heavy soil started later in the spring and weeds had better conditions for growth. Such a number of weeds and weed cover (70\% in June and 30\% in August) may affect the yielding of miscanthus on heavy soil (Fig. 2, Table 5).

\section{DISCUSSION}

Miscanthus is a perennial grass that has been identified as one of the best choices for low input bioenergy production in Europe [18,25,26]. Because perennial energy crops are new species on agricultural lands, there is a need for intensive research on their impact on the environment $[2,10,27]$.

Some authors believe that the cultivation of energy crops increases the biodiversity in agroecosystems $[2,10,12,16]$, but others underline the potential risks associated with the introduction of new plants to agricultural land and the need to observe the changes $[7,27]$. Therefore, ecological monitoring programs should be implemented for these crops, including: flora, avifauna, small mammals, and invertebrates in the soil and above the ground $[4,6,10]$. According to Kovacs-Lang and Simpson [28], long-term monitoring of energy crops should take into account their position in wider agricultural landscape and comparison of their biodiversity with neighboring agricultural crops and semi-natural habitats.

That comparison showed that the number of species and Shannon's diversity index values for the weed community in miscanthus on light soil were similar to those observed in cereals grown in neighboring fields under an integrated farming system in the same conditions and lower than those observed under an ce- reals in organic system [29]. In the weed communities of miscanthus, species typical for arable lands as well as ruderal ones occurred. In the research of $\mathrm{S} \mathrm{e} \mathrm{k} \mathrm{u} \mathrm{-}$ towski and Rola [30], 27 weed species belonging to different classes were observed during a 3-year study and differences in weed composition in particular years of the experiment were negligible. S e m e re and S 1 a t e r [19] showed that miscanthus fields were richer in weed vegetation than reed canary grass or arable fields. According to T u o m i s to et al. [31], miscanthus cultivated in a conventional farming system had the highest biodiversity loss score, being a factor of 2.4 times higher than the score for the organic system and a factor of 4.9 times higher than for the natural forest system. In the study of Felten and Emmerling [32], the number of earthworm species in miscanthus took a medium position and differed significantly neither from intensively managed cereals and maize nor from grassland and fallow.

The study of M a t y k a and Ku ś [33] showed that miscanthus, in order to obtain high yields, does not need to be grown on the best soil, from the agricultural point of view. This plant gives the best yields on soils of average quality, not too heavy. This is particularly important in terms of competition for land resources between production for food and energy. The yields obtained in the cultivation of this plant were dependent on weather conditions, particularly the amount and distribution of rainfall and temperature conditions in the spring. The yields of miscanthus on heavy soil were lower in years with adverse weather conditions, which was caused by the location of the plantations in lower fields. The plants were damaged by frost in late spring, which significantly delayed the start of growth. However, in favorable weather conditions (lack of spring frosts, the temperature in the summer months higher than the average, rainfall exceeded the average of several years), high potential productivity of the fertile soil was revealed [34]. Yields of miscanthus reported for trials all over Europe showed huge differences in biomass yields from 2 to $44 \mathrm{t} \times \mathrm{ha}^{-1}$ [18]. In the opinion of 
M a the - Gas par et al. [35], the growth and yielding of miscanthus and other crops in a given habitat are controlled by the soil and weather conditions as the main environmental factors.

The results of $\mathrm{M}$ a t $\mathrm{y} \mathrm{k}$ a and $\mathrm{K} \mathrm{u}$ ś [34] showed that the dry matter yield of miscanhus was positively correlated with the number of shoots and their length. A comparison of different miscanthus genotypes showed that miscanthus M-115 and Miscanthus giganteus were characterized by the greatest yield [34].

\section{CONCLUSIONS}

1. The weed community was more diversified in miscanthus cultivated on heavy soil. Sorensen's indicators showed low similarity between weed communities in miscanthus grown on light and heavy soil.

2. The number of weeds and percentage weed cover were higher in miscanthus cultivated on heavy soil in comparison with miscanthus grown on light soil.

3. Weed density decreased during the vegetation season as a result of increasing competitiveness of the miscanthus canopy against weeds.

4. The yields of miscanthus were more dependent on weather conditions than the type of soil. Shoot length and diameter as well as leaf area index (LAI) were higher in miscanthus grown on heavy soil.

\section{Acknowledgments}

The research was supported by the Polish Ministry of Science and Higher Education (project NN310 437738 "The assessment of the impact of perennial plants grown for energy purposes on flora biodiversity").

\section{Authors' contributions}

The following declarations about authors' contributions to the research have been made: field research: BFS, MM, MS; data analysis: BFS, MM; writing the manuscript: BFS; comments on the manuscript: MM, MS.

\section{REFERENCES}

1. Szczukowski S, Tworkowski J, Piechocki J. Nowe trendy wykorzystania biomasy pozyskiwanej na gruntach rolniczych do wytwarzania energii [New trends in the use of biomass from agriculture for energy production]. Post Nauk Roln. 2001; 6: 87-96.

2. Faber A. Przyrodnicze skutki uprawy roślin energetycznych [Environmental effects of cultivation of energy crops]. Stud Rap IUNG-PIB. 2008; 11: 43-54.

3. Faber A, Kuś J, Matyka M. Uprawa roślin na potrzeby energetyki [Cultivation of plants for energy purposes]. Warsaw. 2009; 1-29.
4. Brit t C. Methodologies for ecological monitoring in bioenergy crops. A review and recommendations, Defra Project NF0408. 2003; 1-63.

5. European Environmental Agency. How much bioenergy can Europe produce without harming the environment. EEA Report No7, 2006; 1-67.

6. Cunningham MD, Bishop JD, McKay HV, $\mathrm{S}$ a g e R B. ARBRE monitoring - ecology of short rotation coppice. URN 04/961, DTI. 2004; 1-157.

7. Sage RB, Robertson PA, Poulson JG. Enhancing the conservation value of short rotation biomass coppice - phase 1 the identification of wildlife conservation potential. ETSU B/W5/0027/REP. DTI. 1994; 1-119.

8. S a g e R B. Short rotation coppice for energy: towards ecological guidelines. Biomass Bioenergy. 1998; 15: 39-47.

9. Anioł-Kwiatkowska J, Kącki Z, Śliwiński M. Porównanie kompozycji gatunkowej trzech upraw wierzby energetycznej [A comparison of species composition of three energy willow crops]. Pam Pul. 2009; 150: 19-34.

10. Rowe RL, Street NR, Taylor G. 10 - Identifying potential environmental impacts of large-scale deployment of dedicated bioenergy crops in the UK. Renew Sustain Energy Rev. 2009; 13(1): 271-290. http://dx.doi.org/ 10.1016/j.rser.2007.07.008

11. Rola J, Sekutowski T, Rola H, Badowski M. Problem zachwaszczenia plantacji wierzby krzewiastej - Salix viminalis [Weed infestation problem of Salix viminalis plantations]. Prog Plant Prot Post Ochr Roślin. 2006; 46(1): 81-87.

12. Korniak T. Zachwaszczenie upraw wierzby w północnowschodniej Polsce [Weed infestation of willow coppice plantations in north-eastern Poland]. Pam Pul. 2007; 145: 141-149.

13. Rola J, Sekutowski T, Rola H, Badowski M. Bioróżnorodność zbiorowisk chwastów na plantacjach wierzby krzewiastej (Salix viminalis L.) na terenie województwa dolnośląskiego i opolskiego [Biodiversity of weed communities on willow (Salix viminalis L.) plantation in the dolnośląskie and opolskie voivodeship]. Pam Puł. 2007; 145: 165-175.

14. Sekutowski T, Badowski M. Zróżnicowanie zachwaszczenia plantacji Salix viminalis (L.) w zależności od warunków glebowych siedliska [Diversity of weed infestation of Salix viminalis (L.) depending on soil conditions of habitat]. Prog Plant Prot Post Ochr Roślin. 2007; 47(4): 371-378.

15. Trąba C, Majda J, Wolański P. Zbiorowiska roślinne towarzyszące plantacjom Salix cordata „Americana" Hort. i Salix viminalis L. na terenie województwa podkarpackiego [Plant communities associated with Salix cordata „Americana” Hort. and Salix viminalis L. in Podkarpackie Voivodeship]. Pam Puł. 2007; 145: 221-231.

16. Wnuk Z, Ziaja M. Zbiorowiska towarzyszące uprawom roślin dla celów energetycznych w Leszawie Dolnej gmina Bircza [Communities associated with plants cultivated for energy purposes in Leszawa Dolna, Bircza community]. Pam Puł. 2007; 145: 243-253. 
17. Fry DA, Slater FM. The effect on plant communities and associated taxa of planting short rotation willow coppice in Wales. Asp Appl Biol. 2008; 90: 287-293.

18. Lewandowski I, Clifton-Brown JC, Scurlock JMO, Huisman W. Miscanthus: European experience with a novel energy crop. Biomass Bioenergy. 2000; 19(4): 209-227. http://dx.doi.org/10.1016/S0961-9534 (00)00032-5

19. S e mere T, Slater F. Ground flora, small mammal and bird species diversity in miscanthus (Miscanthus $\times$ giganteus) and reed canary-grass (Phalaris arundinacea) fields. Biomass Bioenergy. 2007; 31(1): 20-29. http://dx.doi.org/10. 1016/j.biombioe.2006.07.001

20. Jodl S, Eppel-Hotz A, Marzini K. Examination of the ecological value of Miscanthus expanses - faunistic studies. In: Kopetz H, Weber T, Palz W, Chartier P, Ferrero GL, editors. Proceeding of the 10th European Bioenergy Conference. Würzburg: C.A.R.M.E.N; 1998. p. 778-779.

21. Shan non CE. A mathematical theory of communication. Bell Syst Tech J. 1948; 27(4): 623-656. http://dx.doi.org/ 10.1002/j.1538-7305.1948.tb00917.x

22. Simps on EH. Measurement of diversity. Nature. 1949; 168: 1-668.

23. Magurran AE. Ecological diversity and its measurement. London: Springer Netherlands; 1988. http://dx.doi.org/ 10.1007/978-94-015-7358-0

24. Rutkowski L. Klucz do oznaczania roślin naczyniowych Polski niżowej. Warszawa. Polish Scientific Publishers PWN. 2004; 1-822.

25. Kahle P, Beuch S, Boelcke B, Leinweber $\mathrm{P}$, Schulten HR. Cropping of Miscanthus in Central Europe: biomass production and influence on nutrients and soil organic matter. Eur J Agron. 2001; 15(3): 171-184. http://dx.doi.org/10.1016/S1161-0301(01)00102-2

26. Khanna M, Dhungana B, Clifton-Brown J. Costs of producing miscanthus and switchgrass for bioenergy in Illinois. Biomass Bioenergy. 2008; 32(6): 482-493. http://dx.doi.org/10.1016/j.biombioe.2007.11.003

27. Duer I, Feledyn-Szewczyk B. Monitoring botaniczny w uprawach wieloletnich przeznaczonych na cele energetyczne [Botanical monitoring in perennial bioenergy crops]. Pam Pul. 2009; 150: 105-119.

28. Kovacs-Lang E, Simpson IC. Biodiversity measurements and indicators for long-term integrated monitoring. No LIMITS. 2000; 6: 1-24.

29. Feledyn-Szewczyk B, Duer I, Staniak M. Bioróżnorodność flory segetalnej w roślinach uprawianych w ekologicznym, integrowanym i konwencjonalnym systemie produkcji rolnej [Biodiversity of weed flora in crops cultivated in organic, integrated and conventional production systems]. Pam Pul. 2007; 145: 61-76.

30. Sekutowski T, Rola J. Zbiorowiska chwastów i ich zwalczanie na plantacji Miscanthus giganteus [Weed associations and weed control on a Miscanthus giganteus plantation]. Biul IHAR. 2009; 253: 331-340.

31. Tuomisto HL, Hodge ID, Riordan P, Macdonald DW. Comparing energy balances, greenhouse gas balances and biodiversity impacts of contrasting farming systems with alternative land uses. Agric Syst. 2012; 108: 42-49. http://dx.doi.org/10.1016/j.agsy.2012.01.004

32. Felten D, Emmerling C. Effects of bioenergy crop cultivation on earthworm communities-a comparative study of perennial (Miscanthus) and annual crops with consideration of graded land-use intensity. Appl Soil Ecol. 2011; 49: 167-177. http://dx.doi.org/10.1016/j.apsoil.2011.06.001

33. Matyka M. Produkcyjne i ekonomiczne aspekty uprawy roślin wieloletnich na cele energetyczne [Productive and economic aspects of cultivation of perennial crops for energy purposes] Monografie i Rozprawy Naukowe IUNG-PIB Puławy, 2013; 1-94.

34. Matyka M, Kuś J. Plonowanie i cechy biometryczne wybranych genotypów miskanta [Yielding and biometric characteristics of selected Miscanthus genotypes]. Probl Inż Rol. 2011; 2: 157-163.

35. Mathe-Gaspar G, Fodor N, Pokovai K, Kovacs GJ. Crop modelling as a tool to separate the influence of the soil and weather on crop yields. Phys Chem Earth. 2005; 30(1-3): 165-169. http://dx.doi.org/10.1016/j. pce.2004.08.024

\section{Różnorodność flory segetalnej, wybrane cechy biometryczne i plonowanie miskanta (Miscanthus spp.) uprawianego na glebie lekkiej i ciężkiej}

\section{Streszczenie}

Ważną kwestią związaną z uprawą roślin na cele energetyczne i dotychczas słabo poznaną jest ich oddziaływanie na środowisko, w tym bioróżnorodność. Celem pracy była ocena różnorodności gatunkowej chwastów, wybranych cech struktury łanu i plonowania miskanta, uprawianego na dwóch typach gleb: lekkiej i ciężkiej.

Badania przeprowadzono w Stacji Doświadczalnej Instytutu Uprawy Nawożenia i Gleboznawstwa - Państwowego Instytutu Badawczego, w Osinach (N: $51^{\circ} 28$ E: $\left.22^{\circ} 4\right)$, na plantacjach miskanta (Miscanthus saccharflorus Robustus x M. sinensis - M-115) założonych w 2004 roku, na dwóch typach gleb: piasku gliniastym lekkim i glinie ciężkiej. Analizy flory przeprowadzono w 2010 i 2011 roku, w dwóch terminach: czerwcu i sierpniu, przy użyciu metody ramkowej i zdjęcia fitosocjologicznego. Ponadto przeprowadzono analizy plonu zielonej i suchej masy miskanta, wybranych cech biometrycznych oraz indeksu powierzchni liściowej (LAI).

Badania wykazały, że różnorodność gatunkowa chwastów w łanie miskanta była uzależniona od rodzaju gleby. Większą liczbę gatunków chwastów odnotowano w miskancie uprawianym na glebie ciężkiej 
- 37, w porównaniu z obiektem na glebie lekkiej - 33. Wskaźniki Sorensena wykazały małe podobieństwo zbiorowisk w miskancie uprawianym na glebie lekkiej i ciężkiej. Liczebność i procentowe pokrycie przez chwasty było mniejsze w obiekcie na glebie lekkiej. Poziom zachwaszczenia zmniejszał się w ciągu sezonu wegetacyjnego jako efekt zwiększającej się konkurencyjności łanu miskanta. Plonowanie miskanta zależało bardziej od warunków pogodowych niż od typu gleby. Wysokość roślin, średnica pędów oraz indeks powierzchni liściowej (LAI) były większe w miskancie uprawianym na glebie ciężkiej.

Handling Editor: Elżbieta Weryszko-Chmielewska

This is an Open Access digital version of the article distributed under the terms of the Creative Commons Attribution 3.0 License (creativecommons.org/licenses/by/3.0/), which permits redistribution, commercial and non-commercial, provided that the article is properly cited.

(C)The Author(s) 2014 Published by Polish Botanical Society 